\title{
Editorial expression of concern: The measurement of serum TNF-a levels in patients with lichen planus
}

After the duplicate publication of an article by Yesim Akpinar Kara was identified (1-3), concerns were raised whether other cases of scientific misconduct occurred by the same author. The editorial office of Acta Dermatovenerologica Alpina, Pannonica et Adriatica (Acta Dermatovenerol APA) searched for and reviewed all manuscripts submitted to our journal by Akpinar Kara. In addition to the first case of duplicate publication described in detail in this issue of Acta Dermatovenerol APA (1), we identified another case of duplicate publication by the same author: the article "The measurement of serum tumor necrosis factor-alpha levels in patients with lichen planus” by Y. Akpinar Kara published in the
July/August 2018 issue of Indian Journal of Dermatology (Indian J Dermatol) (PMID: 30078872; DOI: 10.4103/ijd.IJD_474_17) (4) was practically identical to the original article "The measurement of serum TNF-a levels in patients with lichen planus" published in the December 2017 issue of Acta Dermatovenerol APA (PMID: 29264897; DOI: 10.15570/actaapa.2017.26) (5) by the same author. In February 2019, the editorial office of Acta Dermatovenerol APA contacted both the author as well as the editors of Indian J Dermatol. Pending the final resolution of this case, Acta Dermatovenerol APA is publishing this editorial expression of concern.

4. Kara YA. The measurement of serum tumor necrosis factor-alpha levels in patients with lichen planus. Indian J Dermatol. 2018;63:297-300.

5. Akpinar Kara Y. The measurement of serum TNF-a levels in patients with lichen planus. Acta Dermatovenerol Alp Pannonica Adriat. 2017;26:85-88. 